\title{
Determinants of the Intention to Consume Halal Food, Cosmetics and Pharmaceutical Products
}

\author{
Heri SUDARSONOํㅜ, Rindang Nuri Isnaini NUGROHOWATI ${ }^{2}$
}

Received: August 01, 2020 Revised: September 06, 2020 Accepted: September 10, 2020

\begin{abstract}
The purpose of this study was to determine the effect of religiosity, knowledge and attitudes on consumer intention to consume halal food, cosmetics and pharmaceutical products in Indonesia. The data is collected from online questionnaires and the total data used for this study was obtained from a total of 684 respondents from 27 provinces in Indonesia. This study used a quantitative approach because the purpose of this study was to test hypotheses and the relationship between variables such as religiosity, knowledge, attitudes, and intentions to consume halal food, cosmetics and pharmaceutical products. The result of this study indicated that the relationship among religiosity, knowledge and attitudes positively influenced consumer intention to consume halal food, cosmetics and pharmaceutical products. The study also found that religiosity had more influence on consumer intentions to consume halal food than cosmetics and pharmaceuticals products. Meanwhile knowledge had more influence on consumer intention to consume halal pharmaceuticals than cosmetics and food products. In fact, attitude had a positive influence on intention to consume halal food and had a greater influence over it compared to consumption of cosmetics and pharmaceutical products. In addition, this study is one of the first attempts to determine the reason for differences in consumer intentions to consume halal food, cosmetics and pharmaceutical products in Indonesia.
\end{abstract}

Keywords: Religiosity, Halal Food, Halal Cosmetics, Halal Pharmaceuticals

JEL Classification Code: M21, M30, M31, M37

\section{Introduction}

The halal industry has now received the attention of many countries, including ones whose populations are predominantly Muslim and non-Muslim. Consumers of halal products are also growing along with the increase in Muslim population in the world. Currently halal products have become a sort of lifestyle because Muslim communities have become increasingly aware about consumption of halal

${ }^{1}$ First Author and Corresponding Author. Lecturer, Department of Economics, Faculty of Business and Economics, Universitas Islam Indonesia, Indonesia [Postal Address: Gedung Ace Partadiredja, Ring Road Utara, Condongcatur, Sleman, Yogyakarta 55283, Indonesia] Email: heri.sudarsono@uii.ac.id.

${ }^{2}$ Lecturer, Department of Economics, Faculty of Business and Economics, Universitas Islam Indonesia, Indonesia.

Email: rindangnuri@uii.ac.id

(C) Copyright: The Author(s)

This is an Open Access article distributed under the terms of the Creative Commons Attribution Non-Commercial License (https://creativecommons.org/licenses/by-nc/4.0/) which permits unrestricted non-commercial use, distribution, and reproduction in any medium, provided the original work is properly cited. food and products (Amijaya et al., 2019; Hamdan et al., 2013; Mutmainah, 2018). Halal food is not only limited to Muslim consumers, non-Muslim consumers have also started showing interest in halal products because these products are considered cleaner and healthier (Azam, 2016; Haque et al., 2015; Wilson \& Liu, 2010). Positive responses from non-Muslim consumers to halal products has created a new market share which has been utilized by countries globally to develop the halal industry. (Wilkins et al., 2019). The Halal realm is not only limited to food but it covers a broader scope such as banking financial services, fashion, entertainment media and tourism as well as cosmetics and pharmaceuticals (Thomson Reuters, 2018).

One sector that attracts attention in the halal market is that of the halal cosmetics and as a result of this growing interest, the demand manufacturers in non-Muslim countries. This has resulted in a debate about the halal ingredients for halal cosmetics is projected to reach US \$ 25 billion by 2025 (Thomson Reuters, 2018). Despite having a large market share, there are some Muslim consumers who are not aware with the fact that the term halal is also used for cosmetics (Hajipour et al., 2015). On the other hand, most cosmetics products 
are produced by non-Muslim which is used to make these cosmetics products. This situation has caused a distrust among Muslin consumers about global cosmetics and pharmaceutical products. As a result, the cosmetics and pharmaceutical sectors have been the subject of many studies due to the suspicion that many international brands use enzymes extracted from pork or alcohol as preservatives (Mukhtar \& Butt, 2012).

Previous studies have found that halal product users have a high level of loyalty towards halal brand (Ireland \& Rajabzadeh, 2011; Wilson \& Liu, 2010). Research by Shah Alam and Mohamed Sayuti (2011) has revealed that nonMuslim consumers buy halal products because they feel safer when they use halal products than when they use nonhalal products. In addition, non-Muslim consumers perceive halal $\log$ o as a guarantee of safe food products (Aziz \& Chok, 2013). Previous researches in the field has been more about halal food products than other halal products. Research on halal cosmetic products has been carried out by Ireland, Ireland and Rajabzadeh (2011) and Mukhtar and Butt (2012) although it was smaller compared to research on halal food.

This study has tried to examine consumer perceptions of halal food, cosmetics and pharmaceuticals. Research on halal pharmaceuticals is relatively few in number compared to those on food and cosmetics. In fact, studies which cover all the three halal products together has been rarely done. This study aimed to determine the effect of religiosity, knowledge and attitudes on consumer intentions to consume halal food, cosmetics and pharmaceuticals in Indonesia. This research is expected to help food, cosmetics and pharmaceutical producers in Indonesia find strategies to increase market share among Muslims.

\section{Literature Review}

\subsection{Theory of Reasoned Action (TRA)}

TRA was developed to better understand the relationship among attitudes, intentions, and behavior (M. Fishbein, 1967). The theory covered intention to influence behavior and intention influenced by individual attitudes in behavior (M. Fishbein \& Ajzen, 1975). TRA has two elements; the first is attitude-determining behavior. The second element is called subjective norms or a person's perception that whether most people who are important to him/her think that he or she should or should not conduct the behavior in question (M. Fishbein \& Ajzen, 1975). Thus, TRA not only measures an individual's attitude towards an object but also explains the role of the reference group in forming and strengthening that attitude (Lada et al., 2009).

TRA is the most relevant theoretical model in predicting the buying behavior of halal products. Several studies using TRA have been conducted to predict consumer buying behavior, Amin (2013) conducted research using TRA for halal service cases through examining customer preferences for Islamic credit cards. Abd Rahman et al. (2015), Ahmad et al. (2015) and Putri et al. (2018) used TRA to find out the relationship among religiosity, knowledge and attitudes towards intention to consume halal food and cosmetics.

Based on some of the above mentioned studies, we wanted to modify the models developed by Abd Rahman et al. (2015), Ahmad et al. (2015) and Putri et al. (2018) to find out the relationship among religiosity, knowledge and attitudes towards consumer intentions to consume halal food, cosmetics and pharmaceuticals in Indonesia. This study had four hypotheses that were formulated from literature review as follows:

\subsection{Religiosity, Attitudes and Intention}

Religiosity is defined as a doctrine of certain beliefs about divine power or interpreted as a person's relationship with tradition (Wong et al., 2006). Meanwhile Huber \& Huber (2012) interpreted religiosity as one's beliefs about the existence of God and everything that is divine. When someone upholds the teachings of religion because of the development of emotions in the teachings that he believes, is interpreted as religious experience. It is this emotional development that brings individuals an understanding to differentiate between good attitudes and bad attitudes and choose the right one. Thus, religiosity can shape a person's attitudes and behavior (McDaniel \& Burnett, 1990; Park \& Park, 2019).

Religion has an important role in shaping people's decisions in choosing products or food to consume. Dindyal \& Dindyal (2012), Musaiger (1993) and Jamal (2003) asserted that one of the most important factors affecting people's lives and beliefs is religion. Religion acts as a basic foundation on which one builds attitudes and behaviors (Essoo \& Dibb, 2004; Mukhtar \& Butt, 2012). According to Essoo \& Dibb (2004), Jamal (2003) and Mullen et al. (2000) who revealed in the context of consumption theory that religious beliefs will direct one's attitudes and feelings in looking at a product such as food, cosmetics and pharmaceutical products as well as financial services. Meanwhile according to Islamic teachings, Muslim consumption behavior is determined by the laws or rules contained in the Qur'an and Hadith.

Many empirical studies have proven that consumer attitudes and behavior are generally influenced by religion. Dindyal \& Dindyal (2012) and Musaiger (1993) mentioned religion as an important factor in determining food purchasing decisions. A similar view was expressed by Pettinger et al. (2004) in their research they found that religion influences consumer behavior in consuming food. In other words, food choices and consumption patterns are influenced by religion (Mullen et al., 2000; Pollard et al., 1998; Shatenstein \& Ghadirian, 1998). Schiffman \& Kanuk (2004) also found 
that religious identity is a factor that significantly influences the purchase of halal food products. Muslims are required to consume halal food in accordance with the religious teachings (Bonne et al., 2007).The hypotheses in this study can be formulated as follows:

H1: Religiosity has a positive influence on attitudes to consume halal food.

H2: Religiosity has a positive influence on attitudes to consume halal cosmetics.

H3: Religiosity has a positive influence on attitudes to consume halal pharmaceuticals.

H4: Religiosity has a positive influence on the intention to consume halal food.

H5: Religiosity has a positive influence on the intention to consume halal cosmetics.

H6: Religiosity has a positive influence on the intention to consume halal pharmaceuticals.

\subsection{Knowledge, Attitudes and Intention}

Knowledge is an experience, feeling or fact that is known by a person or group of people Bang et al. (2000) and Shepherd \& G. Towler (2007) in their research confirmed that knowledge influences intention through attitude, so increased knowledge will influence intention. In general, knowledge is defined as experience that refers to facts, feelings and awareness gained through learning. More specifically, knowledge is the expertise and skills acquired by a person through theoretical and practical understanding of a subject (Ahmat et al., 2011).

Several previous studies have found that knowledge about the food to be consumed has a positive effect on attitudes towards these foods (Aertsens et al., 2011; Stobbelaar et al., 2007; Putri et al., 2018)). However, not many studies have revealed the influence of knowledge on attitudes towards halal food. Hamdan et al. (2013) showed a weak relationship between knowledge of halal food and purchasing decisions. In contrast, Aziz \& Chok (2013) found that knowledge about halal food positively influenced purchase intentions for non-Muslim consumers. Further, the hypotheses can be formulated as follows:

H7: Knowledge has a positive influence on attitudes to consume halal food.

H8: Knowledge has a positive influence on attitudes to consume halal cosmetics.

H9: Knowledge has a positive influence on attitudes to consume halal pharmaceuticals.

H10: Knowledge has a positive influence on the intention to consume halal food.

H11: Knowledge has a positive influence on the intention to consume halal cosmetics.
H12: Knowledge has a positive influence on the intention to consume halal pharmaceuticals.

\subsection{Attitude and Intention}

Shah Alam and Mohamed Sayuti (2011) in their research found a strong relationship between attitude and consumer intention to make a purchase. The same thing was expressed by Mukhtar \& Butt (2012) who asserted that attitude has a significant influence on the intention to purchase halal food. Positive influence of attitude on intention to buy halal products was also expressed by Lada et al. (2009). Nguyen et al. (2019) in their research found that attitudes have a positive influence on the intention to buy organic cosmetics that are environmentally friendly. Meanwhile Awan (2015) stated that consumer attitudes are based on knowledge and trust about goods or commodities obtained from information gathering process which will further influence consumer goals and behavior.

In the context of social psychology, it is stated that attitude is the best predictor of an individual's actions or behavior (Farhat et al., 2019). In addition, consumer attitude will determine consumer intention to purchase a product or service (Davis et al., 1989). In the context of family takaful, Farhat et al. (2019) found in their research that attitude is a determining factor in one's intention to use family takaful. The hypotheses can be arranged as follows:

H13: Attitude has a positive influence on the intention to consume halal food.

H14: Attitude has a positive influence on the intention to consume halal cosmetics.

H15: Attitude has a positive influence on the intention to consume halal pharmaceuticals.

The research model of individual intention to consume halal food, cosmetics and pharmaceuticals can be illustrated as follows (see Figure 1):

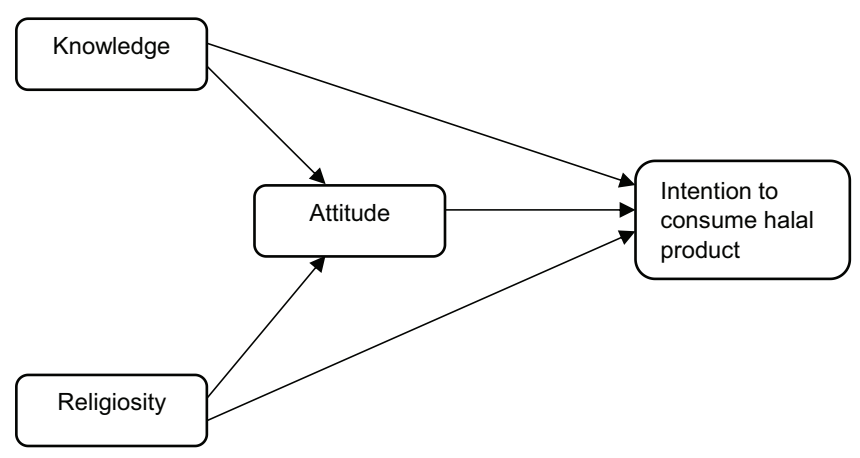

Figure 1: Research model 


\section{Research Methods}

\subsection{Data Collection and Sample Method}

Data was collected using online questionnaires via Google form. Invitation to survey respondents using various media, one of which was through the social media. In addition, respondents also participated in disseminating information so that many people participated in the survey. Based on 684 data samples used in this study, 73.98 percent of the respondents were female. Of the total sample, $56.73 \%$ of the respondents were under 20 years.

In terms of the educational background of the respondents, the majority were high school graduates and equivalent (76.02 percent) and the most of them were students (89.18 percent). In addition, the majority of these respondents had monthly expenditure below IDR 2,500,000 (89.33\%). Meanwhile, $27.63 \%$ of the respondents lived in Central Java, $13.60 \%$ in Yogyakarta, $13.16 \%$ in West Java, $12.43 \%$ in East Java, $6.87 \%$ in Riau and the remaining (less than 3\%) were from several other provinces (see Table 1).

Table 1: Composition of Sample Demography

\begin{tabular}{|l|c|c|}
\hline Characteristic & Total & Persentage \\
\hline Gender & & \\
\hline Male & 178 & $26.02 \%$ \\
\hline Female & 506 & $73.98 \%$ \\
\hline Age & & \\
\hline$<20$ years old & 388 & $56.73 \%$ \\
\hline 21 years old and above & 296 & $43.27 \%$ \\
\hline Education level & & \\
\hline Senior High School & 520 & $76.02 \%$ \\
\hline Bachelor & 151 & $22.08 \%$ \\
\hline Master & 13 & $1.90 \%$ \\
\hline Occupation & & \\
\hline Civil officers & 10 & $1.46 \%$ \\
\hline Private Employees & 40 & $5.85 \%$ \\
\hline Students & 610 & $89.18 \%$ \\
\hline Entrepreneurs & 24 & $3.51 \%$ \\
\hline Monthly spending & & \\
\hline$<$ IDR 2,500,000 & 611 & $89.33 \%$ \\
\hline IDR 2,501,000 and above & 73 & $10.67 \%$ \\
\hline
\end{tabular}

\subsection{Factor Loading and Data Validity}

It can be seen in Table 2 that all the measuring devices in this study had a loading factor value $>0.60$. This situation shows the variation of data on indicators in each latent construct varied quite widely. The reliability test showed that Cronbach's Alpha (CA) in each construct was $>0.70$. This means that all the constructs in this study were reliable or the respondents' answers were consistent. Table 2 shows that the CA value for intention in food, cosmetics and pharmaceuticals was relatively higher compared to those for knowledge, religiosity and attitude. Composite reliability (RA) is a group of indicators that measure a variable, and a variable is said to have a good composite reliability if it has a composite reliability $\geq 0.7$.

In addition, to determine whether the measuring instrument is valid or not, the researchers did other ways by looking at the value of each loading factor on each indicator. Next, it is shown in Table 2 that the average variance extracted (AVE) for each construct was well above the recommended value of 0.5 . This shows that the value of AVE illustrates the magnitude of variance or diversity of manifest variables that can be possessed by the latent constructs of food, cosmetics and pharmaceuticals (see Table 2).

\subsection{Hypothesis Testing}

Analysis of the structure of the model is done after the model meets the reliability and validity requirements. The most common tests performed to determine the fit model are: SRMR, d_ULS, d_G, Chi Square and Normative Fit Index (NFI). Standardized Root Mean Square Residual (SRMR) is used as a measure of goodness of fit to avoid model specification errors (Henseler et al., 2014). SRMR is defined as the difference between observed and expected correlations in the model and is used as an absolute measure of suitable criteria. This model is considered goodness of fit when the SRMR value is less than 0.10 or 0.08 (Hu \& Bentler, 1998). From the test results, it was found that the SRMR value for halal food products, cosmetics and pharmaceutical products models was less than 0.08.

The fit model d_ULS (ie, Euclidean distance squared) and d_G (ie, geodesic distance) are bootstrap-based inferential statistical tests to measure the difference between empirical covariance matrices and implied covariance matrices in composite factor models (Dijkstra \& Henseler, 2015). The criterion for the fit model d_ULS and d_G is that the difference between the correlation matrix implied by the model and the empirical correlation matrix must be insignificant $(p>0.05)$. Conversely, if the difference is significant $(\mathrm{p}<0.05)$, the fit model is not met. From the measurements, it was concluded that the model fit was met because the d_ULS and d_G values for the halal food product, cosmetics and pharmaceutical products models were higher than 0.05 or not significant. 
Table 2: Questionnaire Items and Data Validity

\begin{tabular}{|c|c|c|c|}
\hline & Food & Cosmetics & Pharmaceuticals \\
\hline Knowledge & $\begin{array}{l}\text { CA: } 0.911 ; \text { AVE: } \\
0.738\end{array}$ & $\begin{array}{l}\text { CA: } 0.896 ; \text { AVE: } \\
\quad 0.707\end{array}$ & $\begin{array}{l}\text { CA: } 0.922 ; \text { AVE: } \\
0.761\end{array}$ \\
\hline $\begin{array}{l}\text { I understand Islamic law about Halal and Haram for food / } \\
\text { cosmetics / pharmaceuticals. }\end{array}$ & 0.780 & 0.772 & 0.772 \\
\hline $\begin{array}{l}\text { I feel that I have enough knowledge about which foods / } \\
\text { cosmetics / pharmaceuticals are forbidden by Islam. }\end{array}$ & 0.861 & 0.858 & 0.854 \\
\hline $\begin{array}{l}\text { I have enough knowledge to distinguish between items that } \\
\text { are allowed and those that are forbidden in Islam. }\end{array}$ & 0.840 & 0.846 & 0.839 \\
\hline $\begin{array}{l}\text { I know what ingredients are prohibited in Islam (lard, } \\
\text { alcohol and others). }\end{array}$ & 0.785 & 0.788 & 0.792 \\
\hline $\begin{array}{l}\text { I know why the contents of these ingredients (elements of } \\
\text { lard, alcohol, etc.) are prohibited in Islam. }\end{array}$ & 0.781 & 0.782 & 0.789 \\
\hline Attitude & $\begin{array}{l}\text { CA: } 0.809 ; \text { AVE: } \\
0.724\end{array}$ & $\begin{array}{l}\text { CA: } 0.809 ; \text { AVE: } \\
\text { 0.724: }\end{array}$ & $\begin{array}{l}\text { CA: } 0.809 ; \text { AVE: } \\
0.724\end{array}$ \\
\hline $\begin{array}{l}\text { Halal food / cosmetics / pharmaceutical products are very } \\
\text { important because they have safe ingredients and do not } \\
\text { contain prohibited substances. }\end{array}$ & 0.831 & 0.836 & 0.837 \\
\hline $\begin{array}{l}\text { Using halal food / cosmetic / pharmaceuticals products is } \\
\text { my own choice. }\end{array}$ & 0.861 & 0.864 & 0.861 \\
\hline $\begin{array}{l}\text { Most influential people in my life use halal food / cosmetic / } \\
\text { pharmaceuticals products. }\end{array}$ & 0.860 & 0.853 & 0.854 \\
\hline Religiosity & $\begin{array}{l}\text { CA; } 0.869 ; \text { AVE: } \\
0.656\end{array}$ & $\begin{array}{l}\text { CA: } 0.869 ; \text { AVE: } \\
0.656\end{array}$ & $\begin{array}{l}\text { CA: } 0.869 ; \text { AVE: } \\
0.656\end{array}$ \\
\hline I am happy and willing to pay zakat on time. & 0.888 & 0.862 & 0.887 \\
\hline $\begin{array}{l}\text { I enjoy spending time with friends who uphold the same } \\
\text { religion. }\end{array}$ & 0.808 & 0.876 & 0.862 \\
\hline $\begin{array}{l}\text { I often participate in religious activities in mosque, campus } \\
\text { or other places. }\end{array}$ & 0.886 & 0.819 & 0.864 \\
\hline I often read Islamic books, articles and magazines. & 0.888 & 0.889 & 0.889 \\
\hline $\begin{array}{l}\text { I often watch or listen to programs that contain religious } \\
\text { elements (recitation and others) on TV, YouTube, or other } \\
\text { electronic media. }\end{array}$ & 0.821 & 0.752 & 0.861 \\
\hline Intention & $\begin{array}{l}\text { CA; } 0.919 ; \text { AVE: } \\
0.757\end{array}$ & $\begin{array}{l}\text { CA: } 0.901 ; \text { AVE: } \\
0.718\end{array}$ & $\begin{array}{l}\text { CA: } 0.929 ; \text { AVE: } \\
0.782\end{array}$ \\
\hline $\begin{array}{l}\text { I am willing to pay more for halal certified food / cosmetic / } \\
\text { pharmaceuticals products. }\end{array}$ & 0.878 & 0.862 & 0.902 \\
\hline $\begin{array}{l}\text { I am willing to wait longer to buy food / cosmetic / } \\
\text { pharmaceuticals products that are halal certified. }\end{array}$ & 0.906 & 0.892 & 0.923 \\
\hline $\begin{array}{l}\text { I am willing to look for halal cosmetics in shopping centers } \\
\text { or online stores to be able to buy halal food / cosmetics / } \\
\text { pharmaceuticals. }\end{array}$ & 0.902 & 0.897 & 0.925 \\
\hline $\begin{array}{l}\text { I am willing to travel long distances to buy halal certified } \\
\text { food / cosmetic / pharmaceutical products. }\end{array}$ & 0.889 & 0.807 & 0.902 \\
\hline $\begin{array}{l}\text { I intend to purchase halal food / cosmetic / pharmaceutical } \\
\text { products in the future. }\end{array}$ & 0.768 & 0.770 & 0.760 \\
\hline
\end{tabular}


Table 3: Fit Model

\begin{tabular}{|l|c|c|c|c|c|}
\hline & SRMR & d_ULS & d_G & Chi-Square & NFI \\
\hline Food & 0.048 & 0.401 & 0.207 & 862.373 & 0.895 \\
\hline Cosmetics & 0.052 & 0.468 & 0.204 & 844.499 & 0.888 \\
\hline Pharmaceuticals & 0.048 & 0.393 & 0.213 & 893.125 & 0.900 \\
\hline
\end{tabular}

Normed Fit Index (NFI) is obtained by subtracting 1 by the value of $\mathrm{Chi}^{2}$ from the proposed model divided by the value of $\mathrm{Chi}^{2}$ from the zero model. NFI values range from 0 to 1 . This model can be said to be a fit when the NFI value approaches 1 (Lomoller, 1989). Table 3 shows that the NFI values for halal food products, cosmetics and medicines are $0.895,0.888$ and 0.900 or close to 1 so that the three models can be accepted.

\subsection{Halal Food}

Interpretation of the value of $\mathrm{R} 2$ is the same as interpretation of linear regression of $\mathrm{R} 2$ that is the magnitude of the variability of endogenous variables that can be explained by exogenous variables. According to Chin (1998) the R2 criteria consists of three classifications, namely: R2 values $0.67,0.33$ and 0.19 as substantial, moderate and weak. Changes in the value of R2 can be used to see whether the influence of exogenous latent variables on endogenous latent variables has substantive effects. The results of the data processing showed that R2 attitude was 0.131 while the intention was 0.438 . These results indicated that the latent influence of exogenous religiosity and knowledge had a weak influence on the respondents' attitudes in consuming halal food. Meanwhile the influence of religiosity and knowledge on the intention in consuming halal food was moderate. The findings revealed that attitudes toward halal food influenced the respondents' intention in consuming halal food $(\mathrm{QS}=0.018 ; \mathrm{p}<0.05)$. Meanwhile knowledge influenced attitude $(\mathrm{OS}=0.11 ; \mathrm{p}<0.05)$ and intention $(\mathrm{OS}=0.00 ; \mathrm{p}<0.05)$. This means that these findings support $\mathrm{H} 1, \mathrm{H} 2$ and $\mathrm{H} 3$. Meanwhile, religiosity had a positive effect on attitude (OS $=0.00 ; p<0.05)$ and people's intention in consuming halal food (OS $=0.039 ; \mathrm{p}<0.05)$. This finding supports $\mathrm{H} 4$ and $\mathrm{H} 5$

\subsection{Halal Cosmetics}

The results of the data processing showed that the attitude $\mathrm{R} 2$ was 0.207 while the intention was 0.538 . These results indicated that the latent influence of exogenous religiosity and knowledge had a moderate effect on the attitudes of the respondents in consuming halal food. Meanwhile the influence of religiosity and knowledge on the intention in consuming halal food was moderate. The results of the data processing showed that the attitude towards halal cosmetics had a positive effect on the respondents' intention in using halal cosmetics $(\mathrm{QS}=0.001 ; \mathrm{p}<0.05)$. Meanwhile the respondents' knowledge of halal cosmetics affected attitudes $(\mathrm{OS}=0.000 ; \mathrm{p}<0.05)$ and the respondents' intention in using halal cosmetics $(\mathrm{OS}=0.00 ; \mathrm{p}<0.05)$. This means that these findings support $\mathrm{H} 6, \mathrm{H} 7$ and $\mathrm{H} 8$. In addition, the respondents' religiosity had a positive effect on attitude (OS $=0.00 ; \mathrm{p}<0.05)$ and the respondent's intention in using halal cosmetics $(\mathrm{OS}=0.031 ; \mathrm{p}<0.05)$, meaning that these results support H9 and H10 (see Table 4).

\subsection{Halal Pharmaceuticals}

The results of the data processing on the halal pharmaceuticals model showed that R2 on the attitude of the respondents using halal pharmaceuticals was 0.137 while the intention in using halal pharmaceuticals was 0.598. These results indicated that religiosity and knowledge had a weak influence on the attitudes of the respondents in consuming halal food. Meanwhile the influence of religiosity and knowledge on the intention in using halal pharmaceuticals was moderate. The results of the processed data showed that the attitude towards halal pharmaceuticals had a positive effect on the respondents' intention in using halal pharmaceuticals $(\mathrm{QS}=$ $0.09 ; \mathrm{p}<0.05)$. The respondents' knowledge of halal cosmetics affected attitudes ( $\mathrm{OS}=0.000 ; \mathrm{p}<0.05)$ and the respondents' intention in using halal pharmaceuticals $(\mathrm{OS}=0.00 ; \mathrm{p}<0.05)$. This means that these findings support H11, H12 and H13. Meanwhile, the respondents' religiosity had a positive effect on attitude $(\mathrm{OS}=0.00 ; \mathrm{p}<0.05)$ and the respondents' intention in using halal pharmaceuticals ( $\mathrm{OS}=0.029 ; \mathrm{p}<0.05)$, meaning that these results support $\mathrm{H} 14$ and $\mathrm{H} 15$

Means and standard deviations were generated in this study to summarize the observed data, Means show a summary of the data while standard deviations indicate how well the Means represent the data (Field, 2009). From table 4 , the Mean for the influence of attitude, religiosity and knowledge on the intention to consume halal food, cosmetics and pharmaceuticals are above the standard deviation value. The statistical Means that the halal products observed data are a good fit. 
Table 4: Hypothesis Test

\begin{tabular}{|c|c|c|c|c|c|c|}
\hline & Sample & Mean & STDEV & T Stat & P Values & Result \\
\hline \multicolumn{7}{|c|}{ Food; $R^{2}$ Attitude: $0.131 ; R^{2}$ Intention: 0.438} \\
\hline Attitude -> Intention & 0.076 & 0.075 & 0.032 & 2.365 & 0.018 & Significant \\
\hline Knowledge -> Attitude & 0.107 & 0.107 & 0.042 & 2.547 & 0.011 & Significant \\
\hline Knowledge -> Intention & 0.595 & 0.598 & 0.038 & 15.741 & 0.000 & Significant \\
\hline Religiosity $->$ Attitude & 0.296 & 0.300 & 0.041 & 7.240 & 0.000 & Significant \\
\hline Religiosity -> Intention & 0.075 & 0.076 & 0.036 & 2.068 & 0.039 & Significant \\
\hline \multicolumn{7}{|c|}{ Cosmetics; $R^{2}$ Attitude: $0.207 ; R^{2}$ Intention: 0.538} \\
\hline Attitude -> Intention & 0.109 & 0.110 & 0.033 & 3.286 & 0.001 & Significant \\
\hline Knowledge -> Attitude & 0.315 & 0.316 & 0.034 & 9.282 & 0.000 & Significant \\
\hline Knowledge -> Intention & 0.650 & 0.651 & 0.031 & 21.255 & 0.000 & Significant \\
\hline Religiosity -> Attitude & 0.229 & 0.232 & 0.035 & 6.500 & 0.000 & Significant \\
\hline Religiosity -> Intention & 0.071 & 0.070 & 0.033 & 2.160 & 0.031 & Significant \\
\hline \multicolumn{7}{|c|}{ Pharmaceuticals; $R^{2}$ Attitude: $0.137 ; R^{2}$ Intention: 0.598} \\
\hline Attitude -> Intention & 0.073 & 0.073 & 0.028 & 2.605 & 0.009 & Significant \\
\hline Knowledge -> Attitude & 0.137 & 0.138 & 0.036 & 3.762 & 0.000 & Significant \\
\hline Knowledge -> Intention & 0.712 & 0.714 & 0.028 & 25.680 & 0.000 & Significant \\
\hline Religiosity $->$ Attitude & 0.285 & 0.287 & 0.038 & 7.495 & 0.000 & Significant \\
\hline Religiosity -> Intention & 0.073 & 0.071 & 0.033 & 2.196 & 0.029 & Significant \\
\hline
\end{tabular}

\section{Discussion and Managerial Implication}

This research showed that religiosity and knowledge have a positive effect on people's intention in consuming halal food, cosmetics and pharmaceuticals. The activities of people related to the Islamic religion such as reading Islamic books, seeing and listening to information about religious issues, affect people's understanding of products that can be consumed (halal products) and ones that cannot be consumed (haram products) by Muslims. The study infers that increasing understanding of Islamic teachings will affect people's decisions in consumption of an item. This view was reinforced by Shah Alam \& Mohamed Sayuti (2011) who revealed that people who have a high level of religiosity use Islamic teachings as a source of reference in making the purchase decisions of a product. Besides, religious individuals are more responsible and mature, and adhere to religious teachings.

Based on the test results it is known that religiosity had more influence on people related to consumption of halal food compared to consumption of halal pharmaceuticals and cosmetics. This is relevant to the effect of religiosity on the attitudes to consume halal food which is higher than the attitude to consume pharmaceuticals and cosmetics. This shows that religiosity has an important role in influencing the community in making food-related decision (Musaiger, 1993). Religion can affect people's behavior, especially in buying and consuming food (Bonne et al., 2007; Pettinger et al., 2004). Schiffman \& Kanuk (2004) also found that religious identity is a significant factor in buying halal food products. Muslims have a fundamental reason in their religion to consume halal food (Bonne et al., 2007).

Religiosity has an important role in determining one's intention to consume halal products. Based on the survey results, respondents are of the view that consuming halal products is an obligation. Besides, Islamic teachings strictly prohibit Muslims from consuming products that contain prohibited elements. Thus it can be said that consuming halal products for Muslims is not an option but a necessity that must be implemented. A person who is obedient to his 
religious teachings will have a high level of awareness and he or she will tend to avoid products that are prohibited. Therefore, some respondents consider religiosity as the biggest reason that drives them to consume halal products. This can be considered as a form of adherence to their religious teachings.

Furthermore Shahid et al. (2018) in their findings have confirmed that religiosity is the main motivation for a person to consume halal products, especially halal cosmetics products. Mukhtar \& Butt (2012) also emphasized that religion plays an important role in determining the selection of halal products. There have been other findings as well which reveals the existence of a positive influence between religiosity and intention in consuming halal products, Pettinger et al. (2004), Shatenstein \& Ghadirian (1998), Mullen et al. (2000) and Abd Rahman et al. (2015).

Knowledge influences the attitude and intention of people to consume halal food, cosmetics and pharmaceuticals. This result is consistent with the research of Aziz \& Chok (2013) who found that knowledge about halal food influences the intention of non-Muslims to consume halal foods. Likewise, the results of research by Bang et al. (2000) and Shepherd and G. Towler (2007) found that knowledge has an influence on consumer attitudes towards their intention to consume halal products. Therefore, an increase in knowledge will affect consumer's intentions to be more careful in choosing the products which are consumed. Ahmad et al. (2015). This finding can explain that the knowledge of halal products influences consumer choices for halal products.

The effect of knowledge on the intention to consume halal pharmaceuticals is higher compared to cosmetics and halal food. This situation is due to the fact that individuals emphasize on safer habits in using cosmetics and pharmaceuticals products. Cosmetics and pharmaceuticals are objects of consumption that have a higher risk because it has direct physical and health consequences. Therefore, in selecting food and pharmaceuticals, someone usually needs a recommendation from a doctor or beautician. The extent of the influence of knowledge on consumption of pharmaceuticals, cosmetics, and food products can be seen from the effect of knowledge on individual attitudes. The effect of individual knowledge on individual attitudes to consume halal cosmetics is higher than that for pharmaceuticals and food. This situation is due to the fact that the majority of the respondents in this study were female so the influence of knowledge had more effect on attitudes in using cosmetics products. This finding also showed that attitude directly determines a person's intention to consume halal food, cosmetics and pharmaceuticals products. These results are consistent with the research conducted by Abd Rahman et al. (2015), Khibran, (2019), Rajagopal et al.
(2011) and Bonne et al. (2007), they concluded that there is a positive and significant relation between attitude and intention to purchase halal products such as halal food.

The results of the study revealed the influence of halal food, cosmetics and pharmaceuticals products on consumer intention in consuming halal products. These results can be the basis for the managers of food, cosmetics and pharmaceutical companies to develop marketing strategies. They can combine the results of this research with the government's strategy in developing halal products that are listed in the Islamic economic development master plan in Indonesia (Amijaya et al., 2019). The master plan mentions that the government encourages incentive programs for local and global players to invest in supporting the development of the halal industry chain, starting from raw materials, production, distribution and promotion (Vanany et al., 2019).

In addition, consumers could identify halal products through halal certification which can be seen in the form of a halal logo on food products, cosmetics or pharmaceuticals. Halal certification will make consumers feel safer to consume a halalcertified product than products that are claims to be halal without any visible signs or certifications. Halal certification provides justification for consumers that their attitude to consume food, cosmetics and food is in accordance with Islamic regulations (Dubé et al., 2016). Company managers can collaborate with Halal Certification Agency (BPJPH) and the government that has the authority to issue halal certification. Cooperation with BPJPH is needed as an effort to minimize certification costs, to ease bureaucracy and accelerate the certification process (Hudaefi \& Jaswir, 2019; Utomo et al., 2020).

Managers need to continuously promote halal food, cosmetics and pharmaceutical products. Praswati \& Prijanto (2017) The promotion strategy of the three halal products is not much different even though people pay more attention to halal pharmaceutical products. Therefore, the socialization model of halal food, cosmetics and pharmaceutical products by visualization is not much different but the language used is different because the frequency of consumers consuming food, cosmetics and pharmaceutical products is different. With the development of information technology, company managers can now use social media as a place for online promotion and endorse influencers to introduce halal food, cosmetics and pharmaceutical products to consumers (Abd Rahman et al., 2015; Byun, 2018).

\section{Conclusions and limitations}

This research shows that the level of religiosity has a big influence on consumer intentions to consume halal food, cosmetics and pharmaceuticals. Therefore, companies need to be involved in the efforts to improve community religiosity through ongoing activities to introduce and understand the 
importance of halal product for community. On the other hand, companies need to prioritize halal certification not only on production output in the form of ready-to-consume goods and services but also on production inputs and production processes. Therefore, companies' cooperation with BPJPH is needed to build synergies in the business sector for producing halal products that are suitable for consumers.

This research also emphasizes the importance of knowledge of halal products to increase people's intention in consuming halal food, cosmetics and pharmaceuticals. This shows that companies need to provide information that is delivered to be easily understood and approachable by the public. Social media is a place for companies to deliver information easily, quickly and cheaply through optimal utilization of videos, posters, text and so on.

This research has several limitations. First, the sample consisted of people who were from 27 provinces in Indonesia with $89 \%$ of them being students. It is recommended for future studies to use a sample which covers all the 34 provinces in Indonesia, with a more even age distribution starting from 18 years old until retirement age. Second, using the variables of religiosity, knowledge and attitude has not fully explained the impact of family and environment on individual intentions to consume halal products. It is recommended for future studies to include subjective norm or social influence variables in the model.

\section{References}

Abd Rahman, A., Asrarhaghighi, E., \& Ab Rahman, S. (2015). Consumers and halal cosmetic products: Knowledge, religiosity, attitude and intention. Journal of Islamic Marketing, 6(1), 148-163. https://doi.org/10.1108/JIMA-09-2013-0068

Aertsens, J., Mondelaers, K., Verbeke, W., Buysse, J., \& van Huylenbroeck, G. (2011). The influence of subjective and objective knowledge on attitude, motivations and consumption of organic food. British Food Journal, 113(11), 1353-1378. https://doi.org/10.1108/00070701111179988

Ahmad, A. N., Rahman, A. A., \& Rahman, S. A. (2015). Assessing Knowledge and Religiosity on Consumer Behavior towards Halal Food and Cosmetic Products. International Journal of Social Science and Humanity, 5(1), 10-14. https://doi. org/10.7763/ijssh.2015.v5.413

Ahmat, N. C., Radzi, S. M., Zahari, M. S. M., Muhammad, R., Aziz, A. A., \& Ahmad, N. A. (2011). The effect of factors influencing the perception of price fairness towards customer response behaviors. Journal of Global Management, 2(1), 22-38.

Amijaya, R. N. F., Sholikhin, M. Y., \& Fianto, B. A. (2019). The influence of macroeconomics and population in country of origin on tourist arrivals to Indonesia. Jurnal Ekonomi \& Keuangan Islam, 5(2), 72-79. https://doi.org/10.20885/jeki. vol5.iss2.art4
Amin, H. (2013). Factors influencing Malaysian bank customers to choose Islamic credit cards: Empirical evidence from the TRA model. Journal of Islamic Marketing, 4(3), 245-263. https:// doi.org/10.1108/JIMA-02-2012-0013

Awan. (2015). Management Research Review For Authors. Management Research Review, 38(2). https://doi.org/10.1108/ MRR-08-2013-0185

Azam, A. (2016). An empirical study on non-Muslim's packaged halal food manufacturers: Saudi Arabian consumers' purchase intention. Journal of Islamic Marketing, 7(4), 441-460. https:// doi.org/10.1108/JIMA-12-2014-0084

Aziz, Y. A., \& Chok, N. V. (2013). The Role of Halal Awareness, Halal Certification, and Marketing Components in Determining Halal Purchase Intention Among Non-Muslims in Malaysia: A Structural Equation Modeling Approach. Journal of International Food and Agribusiness Marketing, 25(1), 1-23. https://doi.org/10.1080/08974438.2013.723997

Bang, H. K., Ellinger, A. E., Hadjimarcou, J., \& Traichal, P. A. (2000). Consumer concern, knowledge, belief, and attitude toward renewable energy: An application of the reasoned action theory. Psychology and Marketing, 17(6), 449-468. https:// doi.org/10.1002/(SICI)1520-6793(200006)17:6<449::AIDMAR2 $>3.0 . \mathrm{CO} ; 2-8$

Bonne, K., Vermeir, I., Bergeaud-Blackler, F., \& Verbeke, W. (2007). Determinants of halal meat consumption in France. British Food Journal, 109(5), 367-386. https://doi. org/10.1108/0070700710746786

Byun, S. (2018). Evaluating information technology system using consumer survey: The role of personel product knowledge. Journal of Asian Finance, Economics and Business, 5(4), 117-125. https://doi.org/10.13106/jafeb.2018.vol5.no4.117

Chin, W. W. (1998). The partial least squares approach for structural equation modeling. Modern Methods for Business Research, January, 295-336.

Davis, F. D., Bagozzi, R. P., \& Warshaw, P. R. (1989). User acceptance of computer technology: A comparison of two theoretical models. Management Science, 35(8), 982-1003. https://doi.org/10.1287/mnsc.35.8.982

Dijkstra, T. K., \& Henseler, J. (2015). Consistent and asymptotically normal PLS estimators for linear structural equations. Computational Statistics and Data Analysis, 81, 10-23. https:// doi.org/10.1016/j.csda.2014.07.008

Dindyal, S., \& Dindyal, S. (2012). How Personal Factors, Including Culture And Ethnicity, Affect The Choices And Selection Of Food We Make. The Internet Journal of Third World Medicine, 1(2), 2-5. https://doi.org/10.5580/2231

Dubé, F. N., HaiJuan, Y., \& Lijun, H. (2016). Halal certification system as a key determinant of firm internationalisation in the Philippines and Malaysia. Asian Academy of Management Journal, 21(1), 73-88.

Essoo, N., \& Dibb, S. (2004). Religious Influences on Shopping Behaviour: An Exploratory Study. Journal of 
Marketing Management, 20(7-8), 683-712. https://doi. org/10.1362/0267257041838728

Farhat, K., Aslam, W., \& Sany Sanuri, B. M. M. (2019). Predicting the intention of generation $\mathrm{M}$ to choose family takaful and the role of halal certification. Journal of Islamic Marketing, 10(3), 724-742. https://doi.org/10.1108/JIMA-12-2017-0143

Field, A. (2009). Discovering Statistics Using SPSS (3rd ed.). London, UK: Sage Publications Inc.

Fishbein, M. (1967). Attitude and the Prediction of Behavior. In: M. Fishbein (Ed.), Readings in attitude theory and measurement. New York, NY: John Wiley \& Sons.

Fishbein, M., \& Ajzen, I. (1975). Belief, Attitude, Intention, and Behavior: an Introduction to Theory and Research. New York, NY: Addison-Wesley Publishing.

Hajipour, B., Gharache, M., Hamidizadeh, M. R., \& Mohammadian, F. (2015). Raising Halal Cosmetic Awareness among the respective Consumers. International Journal of Academic Research in Business and Social Sciences, 5(7), 338-349. https://doi.org/10.6007/ijarbss/v5-i7/1745

Hamdan, H., Issa, Z. M., Abu, N., \& Jusoff, K. (2013). Purchasing Decisions among Muslim Consumers of Processed Halal Food Products. Journal of Food Products Marketing, 19(1), 54-61. https://doi.org/10.1080/10454446.2013.724365

Haque, A., Sarwar, A., Yasmin, F., Tarofder, A. K., \& Hossain, M. A. (2015). Non-Muslim consumers' perception toward purchasing halal food products in Malaysia. Journal of Islamic Marketing, 6(Unit 07), 1-5.

Henseler, J., Dijkstra, T. K., Sarstedt, M., Ringle, C. M., Diamantopoulos, A., Straub, D. W., Ketchen, D. J., Hair, J. F., Hult, G. T. M., \& Calantone, R. J. (2014). Common Beliefs and Reality About PLS: Comments on Rönkkö and Evermann (2013). Organizational Research Methods, 17(2), 182-209. https://doi.org/10.1177/1094428114526928

Hu, L., \& Bentler, P. M. (1998). Fit indices in covariance structure modeling: Sensitivity to underparameterized model misspecification. Psychological Methods, 3(4), 424-453. https://doi.org/10.1037//1082-989x.3.4.424

Huber, S., \& Huber, O. W. (2012). The Centrality of Religiosity Scale (CRS). Religions, 3(3), 710-724. https://doi.org/10.3390/ rel3030710

Hudaefi, F. A., \& Jaswir, I. (2019). Halal Governance in Indonesia: Theory, Current Practices, and Related Issues. Journal of Islamic Monetary Economics and Finance, 5(1), 89-116. https://doi.org/10.21098/jimf.v5i1.1049

Ireland, J., \& Rajabzadeh, S. A. (2011). UAE consumer concerns about halal products. Journal of Islamic Marketing, 2(3), 274-283. https://doi.org/10.1108/17590831111164796

Jamal, A. (2003). Marketing in a multicultural world. European Journal of Marketing, 37(11/12), 1599-1620. https://doi. org/10.1108/03090560310495375

Khibran, M. (2019). An investigation toward purchase intention of halal beef from traditional market: A TPB perspective.
Asian Journal of Islamic Management, 1(1), 1-12. https://doi. org/10.1108/AJIM.vol1.iss1.art1

Lada, S., Harvey Tanakinjal, G., \& Amin, H. (2009). Predicting intention to choose halal products using theory of reasoned action. International Journal of Islamic and Middle Eastern Finance and Management, 2(1), 66-76. https://doi. org/10.1108/17538390910946276

Lomoller, J.-B. (1989). Latent Variable Path Modeling with Partial Least Squares. Heildelberg: Physica-Verlag.

McDaniel, S. W., \& Burnett, J. J. (1990). Consumer religiosity and retail store evaluative criteria. Journal of the Academy of Marketing Science, 18(2), 101-112. https://doi.org/10.1007/ BF02726426

Mukhtar, A., \& Butt, M. M. (2012). Intention to choose Halal products: The role of religiosity. Journal of Islamic Marketing, 3(2), 108-120. https://doi.org/10.1108/17590831211232519

Mullen, K., Williams, R., \& Hunt, K. (2000). Irish descent, religion and food consuption in the west of Scotland. Appetite, 34(1), 47-54. https://doi.org/10.1006/appe.1999.0292

Musaiger, A. O. (1993). Socio-Cultural and Economic Factors Affecting Food Consumption Patterns in the Arab Countries. The Journal of the Royal Society for the Promotion of Health, 113(2), 68-74. https://doi.org/10.1177/146642409311300205

Mutmainah, L. (2018). The Role of Religiosity, Halal Awareness, Halal Certification, and Food Ingredients on Purchase Intention of Halal Food. Journal of Islamic Economics, Finance, and Banking, 1(1), 33. https://doi.org/10.12928/ijiefb.v1i1.284

Nguyen, P. N. D., Nguyen, V. T., \& Vo, N. N. T. (2019). Key determinants of repurchase intention toward organic cosmetics. Journal of Asian Finance, Economics and Business, 6(3), 205214. https://doi.org/10.13106/jafeb.2019.vol6.no3.205

Park, H., \& Park, S. (2019). The Effect of Emotional Image on Customer Attitude. Journal of Asian Finance, Economics and Business, 6(3), 259-268. https://doi.org/10.13106/jafeb.2019. vol6.no3.259

Pettinger, C., Holdsworth, M., \& Gerber, M. (2004). Psycho-social influences on food choice in Southern France and Central England. Appetite, 42(3), 307-316. https://doi.org/10.1016/j. appet.2004.01.004

Pollard, T. M., Steptoe, A., \& Wardle, J. (1998). Motives underlying healthy eating: Using the food choice questionnaire to explain variation in dietary intake. Journal of Biosocial Science, 30(2), 165-179. https://doi.org/10.1017/S0021932098001655

Praswati, A. N., \& Prijanto, T. (2017). Measurement Moslem religion in consumer behavior. Journal Ekonomi \& Keuangan Islam, 3(2), 99-108. https://doi.org/10.20885/ jeki.vol3.iss2.art6

Putri, D., Ulhidayati, A., Musthofa, I. A., \& Wardani, A. K. (2018). Single cell protein production of Chlorella sp. using food processing waste as a cultivation medium. IOP Conference Series: Earth and Environmental Science, 131(1). https://doi. org/10.1088/1755-1315/131/1/012052 
Rajagopal, S., Ramanan, S., Visvanathan, R., \& Satapathy, S. (2011). Halal certification: Implication for marketers in UAE. Journal of Islamic Marketing, 2(2), 138-153. https://doi. org/10.1108/17590831111139857

Schiffman, L., \& Kanuk, L. (2004). Consumer Behavior ( $8^{\text {th }}$ ed.). Upper Saddle River, NJ: Prentice-Hall.

Shah Alam, S., \& Mohamed Sayuti, N. (2011). Applying the Theory of Planned Behavior (TPB) in halal food purchasing. International Journal of Commerce and Management, 21(1), 8-20. https://doi.org/10.1108/10569211111111676

Shahid, S., Ahmed, F., \& Hasan, U. (2018). A qualitative investigation into consumption of halal cosmetic products: The evidence from India. Journal of Islamic Marketing, 9(3), 484-503. https://doi.org/10.1108/JIMA-01-2017-0009

Shatenstein, B., \& Ghadirian, P. (1998). Influence on diet, health behaviors and their outcome in select ethnocultural and religious groups. Nutrition, 14(2), 223-230. https://doi. org/10.1016/S0899-9007(97)00425-5

Shepherd, R., \& G. Towler. (2007). Nutrition knowledge, attitudes and fat intake: Application of the theory of reasoned action. Journal of Human Nutrition and Dietetics, 7(3), 213-221. https://10.1111/j.1365-277X.2007.00776.x

Stobbelaar, D. J., Casimir, G., Borghuis, J., Marks, I., Meijer, L., \& Zebeda, S. (2007). Adolescents' attitudes towards organic food: A survey of 15- to 16-year old school children. International Journal of Consumer Studies, 31(4), 349-356. https://doi. org/10.1111/j.1470-6431.2006.00560.x
Thomson Reuters. (2018). State of the Global Islamic Economy Report 2018/19. Retrieved from: https://www. thomsonreuters.com/en/press-releases/2019/february/ thomson-reuters-reports-fourth-quarter-and-full-year-2018results.html.

Utomo, S. B., Sekaryuni, R., Widarjono, A., Tohirin, A., \& Sudarsono, H. (2020). Promoting Islamic financial ecosystem to improve halal industry performance in Indonesia: A demand and supply analysis. Journal of Islamic Marketing. https://doi. org/10.1108/JIMA-12-2019-0259

Vanany, I., Soon, J. M., Maryani, A., \& Wibawa, B. M. (2019). Determinants of halal-food consumption in Indonesia. Journal of Islamic Marketing, 11(2), 516-530. https://doi.org/10.1108/ JIMA-09-2018-0177

Wilkins, S., Butt, M. M., Shams, F., \& Pérez, A. (2019). The acceptance of halal food in non-Muslim countries: Effects of religious identity, national identification, consumer ethnocentrism and consumer cosmopolitanism. Journal of Islamic Marketing, 10(4), 1308-1331. https://doi.org/10.1108/ JIMA-11-2017-0132

Wilson, J. A. J., \& Liu, J. (2010). Shaping the Halal into a brand? Journal of Islamic Marketing, 1(2), 107-123. https://doi. org/10.1108/17590831011055851

Wong, Y. J., Rew, L., \& Slaikeu, K. D. (2006). A systematic review of recent research on adolescent religiosity/ spirituality and mental health. Issues in Mental Health Nursing, 27(2), 161183. https://doi.org/10.1080/01612840500436941 